\begin{tabular}{|l|c|c|c|c|c|}
\hline J. Tek. Ling & Vol.11 & No.1 & Hal. 1 - 6 & Jakarta, Januari 2010 & ISSN 1441-318X \\
\hline
\end{tabular}

\title{
PENURUNAN KADAR COD AIR LIMBAH INDUSTRI PERMEN DENGAN MENGGUNAKAN REAKTOR LUMPUR AKTIF
}

\author{
Titiresmi \\ Peneliti Balai Teknologi Lingkungan, BPPT \\ Gedung 412 Kawasan Puspiptek Serpong Tangerang 15314
}

\begin{abstract}
Pollution in the rivers is generally caused by domestic and industrial waste. Some treatments to solve it can be done individually or collectively. The effort can be physical, chemical, or biological treatments chosen by its form, character, kind, quality, quantity. PT Van Melle Indonesia is a candy company which produces a high biological waste with COD concentration 10000-30000 mg/litre. This paper reports activated sludge reactor performance to decrease the waste's organic content. The reactor is a biological waste water treatment, as a sequence of earlier anaerob process which still has a high COD (700-4000 mg/litre). A continued reactor operation done with retention time variation 24 hours, 18 hours, 12 hours, and 6 hours show reduced COD varied $80-90 \%$. The highest efficiency was $97.59 \%$ from the 24 hours retention time, and the lowest efficiency was $89.5 \%$ from the 6 hours retention time.
\end{abstract}

Keywords: activated sludge reactor, candy industry wastewater

\section{PENDAHULUAN}

\subsection{Latar Belakang}

PT Van Melle Indonesia merupakan perusahaan mitra asing dan pemegang lisensi dari PT Van Melle Holland yang berpusat di Brenda, Belanda. Produksi yang dihasilkan adalah permen dengan berbagai jenis nama dan rasa seperti mint, buahbuahan dan coklat. Proses produksi PT Van Melle Indonesia terdiri atas beberapa tahap yaitu:

1. ROS (Rework of Sugar) merupakan alat untuk mendaur ulang permen yang kurang sempurna (tidak lulus quality) menjadi cairan gula dengan cara pemanasan

2. Sugar Disolver, cairan gula yang berasal dari ROS dipindahkan ke unit ini, kemudian ditambahkan gula kristal (refined sugar) dan dipanaskan menjadi

3. AWM (Automatic Weighting Machine), pada unit ini cairan gula ditambah cairan glukosa dan semua bahan-bahan yang diperlukan sesuai dengan jenis permen yang akan dibuat. Pengukuran dan prosentase bahan dilakukan secara otomatis dan diaduk menjadi adonan permen. Dari AWM khusus untuk jenis permen A dibagi menjadi eksterior cooker (pembuatan permen bagian luar) dan interior cooker (pembuatan permen bagian dalam)

4. Polling, adalah pengadukan dengan tujuan membuat permen menjadi kenyal dan homogen

5. Forming, penambahan rasa dan warna sesuai jenis permen 
6. Coating 1, adalah alat pelapisan eksterior tahap pertama

7. Dying Room, setelah melewati coating 1 permen yang sudah jadi didiamkan dalam satu ruangan selama 24 jam dengan suhu $30-40^{\circ} \mathrm{C}$

8. Coating 2, pelapisan eksterior tahap kedua agar lapisan lebih sempurna

9. Calibration dan Sortilation, pada bagian ini dilakukan pemilahan permen sesuai dengan standard. Permen yang kwalitasnya kurang baik dikembalikan ke ROS

10. Packing, adalah proses pengepakan dan siap untuk dipasarkan.

\subsection{Sumber limbah}

Dalam pembuatan permen tidak menggunakan air, tetapi menggunakan cairan gula, dan limbah yang dihasilkan tidak banyak. Limbah berasal dari tumpahan gula, kebocoran alat, atau tumpahan pada saat penuangan. Sumber limbah cair terbanyak berasal dari pencucian. Semua limbah cair yang berasal dari pabrik akan masuk ke saluran drainase yang berada di dalam pabrik dan dialirkan secara gravitasi ke IPAL. Karena bahan baku utamanya adalah gula, maka kandungan bahan organik dari limbah sangat tinggi dengan kadar COD rata-rata $10.000-30.000 \mathrm{mg} /$ liter dan debit sekitar $50-70 \mathrm{~m}^{3} /$ hari. Limbah domestik berasal dari toilet dengan debit $50 \mathrm{~m}^{3}$ /hari dikumpulkan dalam septik tank. Limbah padatnya diendapkan dan limbah cairnya disalurkan melalui pipa yang ditanam di dalam tanah dan secara gravitasi dialirkan menuju bak aerasi.

Untuk mengatasi limbah tersebut diperlukan unit pengolah limbah yang mempunyai efektifitas tinggi dalam penguraian bahan organik. Proses pengolahannya merupakan gabungan sistem anaerob dan aerob. Dalam percobaan ini digunakan unit pengolah air limbah secara biologis dengan menggunakan sistem lumpur aktif (activated sludge), yang merupakan pengolahan lanjutan dari proses anaerob sebelumnya. Effluen dari proses anaerob mengandung bahan organik yang masih tinggi yaitu antara 700-4.000 mg/liter. Penggunaan reaktor lumpur aktif bertujuan untuk memperbesar kontak antara mikroorganisme dengan substrat yang dipakai. Kelebihan reaktor dengan pertumbuhan tersuspensi ini bila dibandingkan dengan reaktor yang melekat yaitu:

a. kontrol biomassa lebih fleksibel,

b. laju transfer oksigen dan substrat lebih tinggi,

c. laju pembebanan organik lebih tinggi sehingga mengurangi luas lahan yang diperlukan,

d. stabilitas proses lebih tinggi,

e. kwantitas effluen lebih tinggi dan,

f. tidak berbau ${ }^{1}$.

Kelemahan reaktor ini adalah :

a. sering terjadinya sludge bulking

b. kebutuhan oksigen yang cukup besar.

\subsection{Tujuan}

Tujuan dari percobaan ini untuk mengetahui kemampuan reaktor lumpur aktif (activated sludge) skala laboratorium dalam menyisihkan kadar COD dengan variasi waktu tinggal (24 jam; 18 jam; 12 jam dan 6 jam) pada air limbah industri permen yang sebelumnya telah melalui proses pengolahan secara anaerob.

\section{$1.4 \quad$ Ruang Lingkup}

Untuk mencapai tujuan tersebut dilakukan tahapan ${ }^{2,3)}$ persiapan yang terdiri dari:

1. Analisa pendahuluan terhadap karakteristik air limbah yang akan diolah.

2. Penyiapan reaktor skala laboratorium.

3. Pembenihan (seeding), bertujuan untuk memperoleh biomassa yang cukup 
4. Aklimatisasi, bertujuan untuk mendapatkan kultur biomassa yang telah teradaptasi terhadap air limbah yang akan diteliti

5. Pengoperasian reaktor secara kontinu dengan waktu tinggal yaitu $24 \mathrm{jam}, 18 \mathrm{jam}$, 12 jam dan 6 jam adalah untuk mengetahui kemampuan reaktor dalam menyisihkan kadar COD dalam air limbah.

6. Pengambilan sampel dan analisis air limbah hasil pengolahan

7. Pengolahan data dan analisis hasil penelitian

\section{METODOLOGI.}

\subsection{Lokasi:}

Percobaan dilaksanakan di Laboratorium Proses Balai Teknologi, Lingkungan Puspiptek Serpong

\subsection{Analisis Pendahuluan}

Dilakukan untuk mengetahui karakteristik air limbah yang akan diolah, khususnya VSS dan COD

\subsection{Persiapan Reaktor}

Model instalasi skala laboratorium ${ }^{(4)}$ yang digunakan dapat dilihat pada Gambar -1.

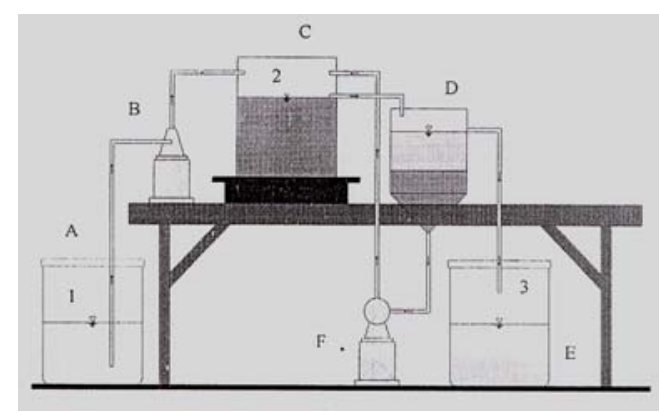

Gambar-1. Instalasi Reaktor

Keterangan:
A :Bak Influen
B : Pompa Influen
C: Bak Aerasi
D: Bak Pengendapan

E: Bak Effluen

F : Pompa Re Sirkulasi

1: titik sampling influen

2: titik sampling reaktor aerasi

3: titik sampling effluen

Karakteristik reaktor lumpur aktif yang digunakan dalam percobaan ini disusun dalam Tabel 1.

\subsection{Pembenihan (Seeding)}

Pembenihan dilakukan untuk memperoleh biomassa dalam jumlah yang mencukupi untuk digunakan dalam penelitian ${ }^{5}$ Pada tahap ini, reaktor dijalankan dengan sistem batch. Sumber mikroorganisme yang digunakan adalah bakteri yang berasal dari tangki aerasi unit pengolahan limbah pabrik permen PT. Van Melle Indonesai. Pemberian glukosa tidak dilakukan setiap hari hanya diberikan setiap dua hari dengan melihat konsentrasi CODnya. Dalam proses ini didapatkan mikroorganisme 3000 mg/1 $5000 \mathrm{mg} / 1$.

Tabel-1. Karakteristik Reaktor

\begin{tabular}{|l|l|}
\hline Uraian & Spesifikasi Teknis \\
\hline 1.Bak Aerasi & $\begin{array}{l}\text { Panjang : 31,5 cm, lebar: 30 } \\
\text { cm, tinggi : 21 cm } \\
\text { Bentuk : lingkaran, jari-jari : } \\
\text { 15cm, tinggi : 21 cm } \\
\text { Bahan acrylic }\end{array}$ \\
\hline $\begin{array}{l}\text { 2.Bak } \\
\text { Pengendapan }\end{array}$ & $\begin{array}{l}\text { Panjang : 50cm, lebar: 20 } \\
\text { cm, tinggi : 20 cm } \\
\text { Bentuk: limas, panjang : } \\
50 \mathrm{~cm} \text {, lebar : 20 cm, tinggi } \\
\text { : 21cm } \\
\text { Bahan acrylic }\end{array}$ \\
\hline 3. Bak Influen \\
dan Effluen & $\begin{array}{l}\text { Kapasitas : 40 liter } \\
\text { Bahan : Plastik }\end{array}$ \\
\hline 4. Aerator & $\begin{array}{l}\text { Suplai udara 1.105 liter/ } \\
\text { menit }\end{array}$ \\
\hline 5. Pompa & Jenis: peristaltik \\
\hline
\end{tabular}




\subsection{Aklimatisasi ${ }^{5}$}

Setelah melalui proses pembenihan, maka dilakukan aklimatisasi. Aklimatisasi adalah pengadaptasian mikroorganisme terhadap air limbah yang akan diolah. Pada proses ini dilakukan dengan sistem bacth karena diharapkan mikroorganisme dapat tumbuh dan berkembang biak serta beradaptasi dengan kondisi baru. Pengapdaptasian dilakukan dengan cara mengganti pemberian glukosa dengan air limbah pabrik permen. Akhir dari proses ini adalah konsentrasi COD menjadi stabil dengan efisiensi penyisihan lebih besar dari $80 \%$.

\subsection{Pengoperasian Reaktor}

Penelitian ini dilakukan dengan mengoperasikan reaktor secara kontinu dengan variasi waktu tinggal yaitu 24 jam, 18 jam, 12 jam dan 6 jam.

Dengan demikian debit untuk masing - masing waktu tinggal akan berbeda, dimana debit adalah volume kerja dibagi waktu tinggal. ${ }^{6)}$ Pada akhir proses ini diketahui bahwa waktu tinggal yang optimum dalam menyisihkan bahan - bahan organik, tertera pada Tabel-2 berikut ini.

Tabel-2. Variasi Waktu Tinggi dan Debit.

\begin{tabular}{|c|c|}
\hline Waktu tinggal & Debit \\
\hline$($ jam $)$ & $($ l/jam $)$ \\
\hline 24 & 1,458 \\
\hline 18 & 1,944 \\
\hline 12 & 2,916 \\
\hline 6 & 5,833 \\
\hline
\end{tabular}

\subsection{Analisa Parameter}

Parameter yang dianalisis adalah VSS (Volatile Suspended Solid) dan kebutuhan oksigen kimiawi (COD). VSS adalah untuk mengetahui banyaknya mikroorganisme yang hidup. Nilai VSS merupakan indikator adanya mikroorganisme yang aktif dan memegang peranan penting dalam proses biologis. Pengukuran ini digunakan dengan menggunakan metode gravimetri. ${ }^{6}$ Sedangkan kebutuhan oksigen kimiawi (COD) adalah banyak oksigen yang dibutuhkan untuk mengoksidasi zat - zat organik yang terdapat didalam air limbah. Metode yang digunakan adalah metode bikromat (K2Cr2O7). ${ }^{6)}$

\section{HASIL DAN PEMBAHASAN}

\subsection{Umum}

Pada bab ini akan diuraikan hasil penelitian dan analisa data yang diperoleh selama penelitian yaitu meliputi :

1. Karakteristik air limbah

2. Tahap pembenihan (seeding)

3. Tahap aklimatisasi

4. Tahap pengoperasian reaktor secara kontinu.

\subsection{Karakteristik Air Limbah}

Sebelum melakukan penelitian terlebih dahulu dilakukan penelitian pendahuluan terhadap limbah pabrik permen. Karakteristik air limbah efluen aerob pabrik permen menunjukkan bahwa konsentrasi air limbah melebihi baku mutu limbah cair bagi kegiatan industri ${ }^{7}$, yaitu sebesar $1070 \mathrm{mg} / \mathrm{l}$.

Sehingga diperlukan suatu unit pengolahan yang dapat mengolah air limbah industri permen sebelum dibuang ke badan air penerima

\subsection{Pembenihan (seeding)}

Pembenihan merupakan tahapan awal sebelum penelitian. Tujuan dari proses ini adalah untuk mendapatkan suatu populasi mikroorganisme yang mencukupi untuk memulai penelitian proses lumpur aktif dan mampu mengoksidai zat - zat organik yang terkandung didalam air limbah.

Dalam penelitian ini mikroorganisme yang digunakan berasal dari bak aerasi. Pada tahap ini diharapkan mikroorganisme tersebut dapat tumbuh dan berkembang biak dengan baik dengan pemberian nutrien dan oksigen secara teratur. Parameter 
yang diamati adalah VSS dan COD. Pada hari pertama pembenihan, COD adalah sebesar $610,22 \mathrm{mg} / \mathrm{l}$ dan konsentrasi VSS adalah sebesar $3096 \mathrm{mg} / \mathrm{l}$. Pada waktu seeding 1 bulan, konsentrasi VSS cukup tinggi yaitu $3000 \mathrm{mg} / \mathrm{l}-6000 \mathrm{mg} / \mathrm{l}$. Namun demikian proses aklimatisasi masih belum dapat dilakukan karena efisiensi penyisihan COD masih belum stabil dan lumpur susah mengendap. Oleh karenanya selama 57 - 75 hari pemberian nutrien dihentikan sehingga terjadi penurunan VSS menjadi $4000 \mathrm{mg} / \mathrm{l}$. Selanjutnya pada pengoperasian hari ke 78 nutiren diberikan kembali dan terlihat pertumbuhan VSS sejalan dengan bertambahnya konsentrasi COD yang diberikan. Pada hari ke 94 hingga hari ke 118 efisiensi penyisihan COD sudah terlihat lebih dari $80 \%$. Hasil akhir dari proses ini adalah VSS mencapai $3122 \mathrm{mg} / \mathrm{l}$ dan penyisihan COD $91,40 \%$, sehingga dapat dilakukan tahapan selanjutnya yaitu aklimatisasi.

\subsection{Aklimatisasi}

Setelah melalui proses pembenihan, dimana mikroorganisme yang tumbuh cukup banyak maka dapat dilakukan tahap aklimatisasi pada reaktor lumpur aktif yang mempunyai kapasitas 35 liter. Pada tahap ini pengoperasian dijalankan dengan sistem batch karena diharapkan mikroorganisme yang ada dapat tumbuh dan berkembang biak dengan baik serta dapat beradaptasi dengan kondisi yang baru.

Pemberian air limbah permen dilakukan secara bertahap dimana 2 liter air limbah dengan COD dikondisikan 1000 $\mathrm{mg} / \mathrm{l}$ dan terus bertambah hingga 15 liter air limbah dengan COD dikondisikan 1500 $\mathrm{mg} / \mathrm{l}$.

Pada hari ke-1 hingga hari ke-21 dapat dilihat bahwa konsentrasi VSS menurun, hal ini dikarenakan mikroorganisme sedang beradaptasi dengan air limbah permen. Pada hari ke-22 hingga ke-60 konsentrasi VSS stabil antara $3000 \mathrm{mg} / \mathrm{l}$ hingga 4000 $\mathrm{mg} / \mathrm{l}$, terus meningkat seiring dengan meningkatnya penyisihan COD. Pemberian air limbah permen secara bertahap membuat konsentrasi VSS dan penyisihan COD meningkat. Hasil akhir penelitian ini adalah air limbah permen yang diberikan sebanyak 15 liter dengan efisiensi yang sudah stabil, yaitu sebesar $98.08 \%$.

\subsection{Pengoperasian Reaktor Secara Kontinu}

Setelah melalui tahap aklimatisasi dengan efesiensi penyisihan $98,08 \%$ dan air limbah secara bertahap diberikan hingga $1 / 2$ volume bak aerasi yaitu sebesar 15 liter maka pengoperasian reaktor secara kontinu dapat dilakukan.

Tabel 3. Waktu tinggal dengan efesiensi Penyisihan

\begin{tabular}{|c|l|l|l|l|l|}
\hline Waktu & \multicolumn{5}{|c|}{ \% Penyisihan COD } \\
\hline Tinggal & 1 & 2 & 3 & 4 & 5 \\
\hline 24 & 95.84 & 94.80 & 95,48 & 96,72 & 97,59 \\
\hline 18 & 91.33 & 94.61 & 94,81 & 97,81 & 97,48 \\
\hline 12 & 94.59 & 95.43 & 96,30 & 96,30 & 96,81 \\
\hline 6 & 88.49 & 89,61 & 88,93 & 88,93 & 89,15 \\
\hline
\end{tabular}

Pengoperasian reaktor ini dilakukan waktu tinggal 24 jam, 18 jam, 12 jam dan 6 jam dengan debit yang dialirkan sesuai dengan waktu tinggal. Sampling yang diambil adalah untuk mengukur parameter COD. Pengoperasian dimulai dari waktu tinggal terlama hingga waktutinggal tercepat. Dapat dilihat pada tabel 3

\section{KESIMPULAN}

1. Efesiensi penyisihan COD pada waktu tinggal 24 jam, 18 jam, dan 12 jam yaitu lebih besar dari $90 \%$, sehinnga di dapat COD efluen yang memenuhi baku mutu.

2. Efesiensi tertinggi adalah pada waktu tinggal 24 jam yaitu sebesar $97,59 \%$ dengan COD 76,54 mg/l.

3. Efesiensi terendah adalah pada waktu tinggal pada 6 jam yaitu sekitar $89,15 \%$ dengan COD efluen 161,55 $\mathrm{mg} / \mathrm{l}$. 


\section{DAFTAR PUSTAKA}

1. Huang, Chang J, A/O (1995) Activated Sludge System. Asia's Journal of environmental Technology.

2. Djajadiningrat, A.H dan Wisjnuprpto. 1978. Bioreaktor Pengolahan Limbah Cair. Bandung : Institut teknologi Lingkungan.

3. Wisnujuprapto \& Djajadiningrat A. 1990. Bioreaktor Pengolahan Limbah Cair. Pusat Antar Universitas Bioteknologi.

4. Benefield, Larry D and Randall, clifford. W. 1980. Biological Processes Design. For Wastewter Treatment. New York : Prentice.
5. Horan, N.J. 1990. Biological Wastewater Treatment Theory And Application. England : John Willey and Sons.

6. Alaert G. \& Sumestri, Sri S. 1987. Metoda Penelitian Air. Surabaya : USaha Nasional.

7. Anonim. 1995, Surat Keputusan Menteri Negara Lingkungan Hidup, Kep-51/MENLH/10/1995 tanggal 23 Oktober 1995. Buku Mutu Limbah Kegiatan Industri. Jakarta : Badan Pengendalian Dampak Lingkungan. 